\title{
Profile of Ramadhan Fasting Effects On Lipid and Insulin Resistance In Obesity Patients
}

\author{
Frihastina Lubis, Santi Syafril *, Dharma Lindarto* \\ *Division of Endocrinology and Metabolic Diseases \\ Department of Internal Medicine \\ Faculty of Medicine Universitas Sumatera Utara \\ DOI: 10.29322/IJSRP.11.06.2021.p11455 \\ http://dx.doi.org/10.29322/IJSRP.11.06.2021.p11455
}

\begin{abstract}
Background: Obesity is associated with insulin resistance, lipid metabolism disorders, and metabolic syndrome. Adipose tissue in obese patients tends to have low-grade chronic inflammation that secretes inflammatory mediator cells and adipokines that block insulin signaling pathways. Ramadan fasting, which is prolonged intermittent fasting, is thought to have beneficial effects in losing weight and body fat, improving lipid profiles, and increasing insulin sensitivity.

Methods: This study is a prospective cohort observational study that was conducted in March-May 2019 at the outpatient installation of the RS Haji Adam Malik Hospital Medan with the approval of the USU Faculty of Medicine Research Ethics Commission. Thirty subjects who met the inclusion criteria were included in this study. Anthropometric measurements, examination of lipid profiles, fasting blood sugar and fasting insulin, and HOMA-IR calculations were carried out one week before Ramadan fasting and in the fourth week of Ramadan. Data were analyzed using the SPPS program. A p-value $<0.05$ was considered statistically significant.

Results: This study found a significant reduction in body weight ( $p<0.001)$ and BMI ( $p<0.001)$ after Ramadan fasting. Serum total cholesterol levels decreased significantly $(\mathrm{p}<0.001)$ and serum HDL levels increased significantly ( $\mathrm{p}<0.05)$ after Ramadan fasting, while serum LDL levels did not change significantly. The HOMA-IR value decreased significantly after Ramadan fasting ( $\mathrm{p}<0.001)$.

Conclusion: This study shows that prolonged intermittent fasting such as Ramadan fasting can improve insulin sensitivity, improve lipid profile and reduce body weight and body mass index in obese non-diabetic patients undergoing Ramadan fasting.
\end{abstract}

Index Terms- Ramadan fasting, insulin resistance, obesity

\section{INTRODUCTION}

$\mathrm{O}$ besity is a disease characterized by excessive weight gain caused by many factors. In 2015, the prevalence of obesity is estimated at 1.9 billion people and overweight is estimated at 609 million people worldwide, which represents $39 \%$ of the world's population (Chooi et al, 2018). Obesity is associated with insulin resistance, changes in lipid metabolism, and metabolic syndrome (Bays et al, 2013). Obesity causes low-grade chronic inflammation due to altered pro-inflammatory adipokine secretion by adipocyte tissue (Fontana et al, 2015). Inflammation is an important bridge between obesity and insulin resistance (Lumeng and Saltiel, 2011; Ellulu et al, 2017). Several pro-inflammatory mediators and cytokines inhibit insulin signaling pathways in adipocytes and hepatocytes through various mechanisms, thereby causing insulin resistance (Chen et al, 2004; Ye, 2013; Wu and Ballantyne, 2020). On the other hand, increased upper body visceral and subcutaneous adipose tissue (apple-shaped obesity) is associated with high triglyceride levels and low levels of high-density lipoprotein (HDL). Disorders of lipid metabolism in obesity may be caused by an increase in free fatty acids from adipose tissue to the liver, insulin resistance, and a pro-inflammatory state (Arora et al, 2016; Bays et al, 2013).

Ramadan fasting is one of the obligatory acts of worship for Muslims around the world which is carried out for a full month in the month of Ramadan (Hijriyah Calendar). Ramadan fasting is carried out by holding back eating and drinking, smoking, and sexual activity from sunrise to sunset (Shehab et al, 2012). Changes in life patterns that occur in the month of Ramadan, namely, reducing the frequency of large meals from 3 times to 2 times in 24 hours, changes in sleep patterns where it is recommended to pray a lot at night so that nighttime sleep shifts to daytime, increased physical activity during worship and reduced smoking time due to a smoking ban during the day (Mohammadzade et al, 2017). Changes in lifestyle for a full month are thought to affect body weight and metabolic processes, particularly lipid profiles and inflammatory mediators, and insulin sensitivity (Mattsona et al, 2016; Aksungar, 2007; Faris et al, 2012).

Several studies have reported the benefits of Ramadan fasting in reducing insulin resistance. Shariatpanahi et al found an increase in the QUICKI value after Ramadan fasting, while Prasetya and Sapwarobol found a decrease in the value of HOMAIR after Ramadan fasting (quantitative insulin sensitivity check index) after Ramadan fasting. (Shariatpanahi et al. 2008; Unalacak et al, 2011; Prasetya and Sapwarobol, 2018). In contrast to others, research by Kamble and Hiremath concluded that there was no change in indicators of insulin resistance in healthy individuals who fasted during Ramadan. Apart from affecting insulin sensitivity. Ramadan fasting can also improve lipid profile parameters. A meta-analysis by Mirmiran et al reported that there were improvements in lipid profile parameters, especially HDL cholesterol in people who fasted during Ramadan (Mirmiran et al, 2019). On the other hand, Ongsara et al who observed that there was no change in body weight and lipid profile after undergoing 
Ramadan fasting (Ongsara et al, 2017). Based on these differences, the researchers aimed to evaluate the effect of Ramadan fasting on lipid profiles and insulin resistance, especially in obese patients.

\section{METHODS}

\section{Subjects}

A total of 30 subjects, obese men and women (BMI $\geq 25 \mathrm{Kg}$ / m2) aged 20-65 years who observe Ramadan fasting participated in this study. Obese subjects who consume long-term drugs (hormonal drugs, corticosteroids, anti-diabetic drugs, cholesterollowering drugs), acute myocardial infarction, inflammatory and malignant arthritis, as well as systemic diseases (diabetes mellitus, chronic kidney disease) and hormonal diseases (thyroid disease), growth hormone disorders, reproductive disorders, and adrenal hormone disorders) were excluded. Research subjects fasted 14 hours for 28-30 days. Informed consent was signed by all research subjects.

\section{Data collection and blood samples}

Venous blood samples were taken from the cubital vein of the subject's left arm after fasting for 10-12 hours, 1 week before the fast of Ramadan (09.00-10.00 am) and in the fourth week of Ramadan (after fasting for 21 days) at 09.00-10.00 am. Blood samples were centrifuged to separate from plasma, then stored in a freezer (at $-20^{\circ} \mathrm{C}$ ) for biochemical analysis. Anthropometric measurements were also carried out 1 week before Ramadan and in the fourth week of Ramadan (after fasting for 21 days). Measurement of body weight (subjects wearing minimal clothing, removing jackets, removing used accessories and bare feet) using a digital scale weight scale (Kris). Height was measured using a microtoise (stature meter) with the subject standing upright, looking straight ahead, and barefoot. The calculation of Body Mass Index (BMI) can be calculated by the formula body weight (kg) divided by height $(\mathrm{m} 2)$. Waist circumference is measured with a non-elastic tape measure by measuring the length of the circumference measured between Crista Iliaca and Costa XII at the smallest circumference. Hip circumference is measured with a non-elastic tape measure by measuring the length of the circumference which is measured at the maximum circumference of the buttocks and the top of the os symphysis pubis. The ratio of the waist to the hip is calculated by dividing the waist circumference by the size of the hip. Blood pressure is measured with a mercury sphygmomanometer in $\mathrm{mmHg}$ with a calm sitting position on the right arm and rest for at least 5 minutes. Lipid profile examination (total cholesterol, LDL, HDL) was measured using colorimetric enzymatic methods. Insulin checks were carried out by the chemiluminescent (sandwich) immunoassay method, with materials in the form of serum/plasma Liheparin/plasma K3-EDTA/plasma sodium citrate.

\section{Statistical Analysis}

Analysis and presentation of data using statistical analysis with Statistical Product and Service Solution (SPSS) 22.0 for Windows software. To assess whether the sample is normally distributed or not, use the Shapiro-Wilk Test (number of samples below fifty). The results of the study were statistically analyzed using the dependent t-test if the data were normally distributed, and if the data were not normally distributed, the Wilcoxon test was used. The correlation between changes in HOMA-IR values with changes in anthropometry, BMI, and lipid profile levels was analyzed using the Spearman correlation test. A P value $<0.05$ was considered statistically significant.

\section{RESULTS}

\section{Research subjects characteristics}

A total of 34 obese subjects who had met the inclusion and exclusion criteria participated in this study (table 1), but at the end of the study, 4 people lost to follow-up because they were not present at the re-examination after fasting in Ramadan, bringing the total subject to 30 people. Based on gender, the majority of subjects were male, amounting to 27 people $(90 \%)$ while female subjects were 3 people $(10 \%)$. The mean age of the subjects was $27.2 \pm 3.9$ years. The mean systolic blood pressure of the study subjects was $120.8 \pm 9.2 \mathrm{mmHg}$. The mean diastolic blood pressure of the study subjects was $82.4 \pm 9.8 \mathrm{mmHg}$. The mean height of the research subjects was $170.6 \pm 6.7 \mathrm{~cm}$. The mean bodyweight of the research subjects was $90.8 \pm 18.6 \mathrm{~kg}$. The mean BMI of research subjects was $29.2(25.2-42.5) \mathrm{kg} / \mathrm{m} 2$. The average waist circumference of the research subjects was $100.9 \pm$ $13.5 \mathrm{~cm}$. The average hip circumference of the research subjects was $110.3 \pm 10.8 \mathrm{~cm}$. The average waist/hip circumference ratio of the study subjects was $1.03(0.92-1.08)$. The mean total cholesterol level of the study subjects was $199.7 \pm 34.4 \mathrm{mg} / \mathrm{dl}$. The mean HDL cholesterol level in the study subjects was $49.4 \pm 8.2$ $\mathrm{mg} / \mathrm{dl}$. The mean LDL cholesterol level in the study subjects was $130.1 \pm 28.4 \mathrm{mg} / \mathrm{dl}$. The mean LDL/total cholesterol ratio of the study subjects was $0.26 \pm 0.07$. The mean HOMA-IR value of the research subjects was $2.80(1,15-10,46)$.

\section{Table 1 Research subject characteristics}

\begin{tabular}{|c|c|c|}
\hline Characteristics & $\mathrm{n}=\mathbf{3 0}$ & $\%$ \\
\hline \multicolumn{3}{|l|}{ Gender } \\
\hline Male & 27 & 90 \\
\hline Female & 3 & 10 \\
\hline Age $(\text { years })^{\mathrm{a}}$ & $27,2 \pm 3,9$ & \\
\hline Systolic blood pressure & $120,8 \pm 9,2$ & \\
\hline$(\mathrm{mmHg})^{\mathrm{a}}$ & $82,4 \pm 9,8$ & \\
\hline \multicolumn{3}{|l|}{$\begin{array}{l}\text { Diastolic blood pressure } \\
(\mathrm{mmHg})^{\mathrm{a}}\end{array}$} \\
\hline Height $(\mathrm{cm})^{\mathrm{a}}$ & $170,6 \pm 6,7$ & \\
\hline Weight $(\mathrm{kg})^{\mathrm{a}}$ & $90,8 \pm 18,6$ & \\
\hline $\operatorname{IMT}\left(\mathrm{kg} / \mathrm{m}^{2}\right)^{\mathrm{b}}$ & $29,2(25,2-42,5)$ & \\
\hline Waist circumferences & $100,9 \pm 13,5$ & \\
\hline$(\mathrm{cm})^{\mathrm{a}}$ & $110,3 \pm 10,8$ & \\
\hline \multicolumn{3}{|l|}{ Hip circumferences $(\mathrm{cm})^{\mathrm{a}}$} \\
\hline Waist-hip circumferences & $1,03(0,92-1,08)$ & \\
\hline ratio $^{\mathrm{b}}$ & $199,7 \pm 34,4$ & \\
\hline Total cholesterol $(\mathrm{mg} / \mathrm{dL})^{\mathrm{a}}$ & $49,4 \pm 8,2$ & \\
\hline $\mathrm{HDL}(\mathrm{mg} / \mathrm{dL})^{\mathrm{a}}$ & $130,1 \pm 28,4$ & \\
\hline $\mathrm{LDL}(\mathrm{mg} / \mathrm{dL})^{\mathrm{a}}$ & $2,80 \quad(1,15-$ & \\
\hline HOMA-IR & $10,46)$ & \\
\hline
\end{tabular}

${ }^{a}$ normal distribution, mean $\pm \mathrm{SD}$

${ }^{\mathrm{b}}$ abnormal data distribution; median (min-max); the Wilcoxon test 
2. Changes in Hemodynamic and Anthropometric Parameters before and After Ramadan Fasting

Changes in hemodynamic and anthropometric parameters before and after Ramadan fasting can be seen in Table 2.

Table 2. Changes in Subject Hemodynamic and Anthropometric Parameters Before and After Ramadan Fasting

\begin{tabular}{|c|c|c|c|}
\hline Characteristics & P1 $(n=30)$ & P2 $(n=30)$ & $\mathbf{P}$ \\
\hline $\begin{array}{lr}\text { Systolic } \quad \text { blood } \\
\text { pressure }(\mathrm{mmHg})^{\mathrm{a}}\end{array}$ & $120,8 \pm 9,2$ & $119,7 \pm 11,3$ & 0,475 \\
\hline $\begin{array}{l}\text { Diastolic blood } \\
\text { pressure }(\mathrm{mmHg})^{\mathrm{a}}\end{array}$ & $82,4 \pm 9,8$ & $81,1 \pm 10,5$ & 0,417 \\
\hline Weight $(\mathrm{kg})^{\mathrm{a}}$ & $90,8 \pm 18,6$ & $89,4 \pm 18,5$ & $<0,001 * *$ \\
\hline IMT $\left(\mathrm{kg} / \mathrm{m}^{2}\right)^{\mathrm{b}}$ & $\begin{array}{l}29,2 \quad(25,2- \\
42,5)\end{array}$ & $\begin{array}{l}28,8 \quad(25,1- \\
42,0)\end{array}$ & $<0,001 * *$ \\
\hline $\begin{array}{l}\text { Waist } \\
\text { circumferences } \\
(\mathrm{cm})^{\mathrm{a}}\end{array}$ & $100,9 \pm 13,5$ & $98,7 \pm 12,0$ & $0,016^{*}$ \\
\hline $\begin{array}{l}\text { Hip } \\
\text { circumferences } \\
(\mathrm{cm})^{\mathrm{a}}\end{array}$ & $110,3 \pm 10,8$ & $108,3 \pm 10,2$ & $0,005^{*}$ \\
\hline $\begin{array}{l}\text { Waist-hip } \\
\text { circumferences } \\
\text { ratio }^{\mathrm{b}}\end{array}$ & $\begin{array}{l}1,03 \quad(0,92- \\
1,08)\end{array}$ & $\begin{array}{l}0,92 \quad(0,80- \\
1,01)\end{array}$ & $<0,001 * *$ \\
\hline
\end{tabular}

${ }^{a}$ normal distribution, mean $\pm \mathrm{SD}$, paired $\mathrm{t}$ test

${ }^{\mathrm{b}}$ abnormal data distribution; median (min-max); the Wilcoxon test $* \mathrm{p}<0,05 ; * * \mathrm{p}<0,001$

P1 before the fast of Ramadan

P2 after the fast of Ramadan

There was no significant difference in the mean systolic blood pressure and the mean Diastolic blood pressure of the study subjects before and after Ramadan fasting (p 0.475 and p 0.417). There were significant differences in body weight and BMI of research subjects before and after Ramadan fasting ( $p<0.001$ and $\mathrm{p}<0.05$ ) (table 4.2). The average bodyweight of the research subjects before Ramadan fasting was $90.8 \pm 18.6 \mathrm{~kg}$ and after Ramadan fasting it was $89.4 \pm 18.5 \mathrm{~kg}$. The median BMI of research subjects before Ramadan fasting was $29.2(25.2-42.5) \mathrm{kg}$ $/ \mathrm{m} 2$ and after Ramadan fasting was $28.8(25.1-42.0) \mathrm{kg} / \mathrm{m} 2$. There was a decrease in body weight and BMI which were statistically significant after Ramadan fasting.

The study subjects' waist circumference, hip circumference, and waist/hip ratio before and after Ramadan fasting also showed a significant decrease. The average waist circumference of research subjects before Ramadan fasting was $100.9 \pm 13.5 \mathrm{~cm}$ and after Ramadan fasting it was $98.7 \pm 12.0 \mathrm{~cm}(\mathrm{p}=0.016)$. The average hip circumference of the research subjects before Ramadan fasting was $110.3 \pm 10.8 \mathrm{~cm}$, changing to $108.3 \pm 10.2$ $(\mathrm{p}=0.005)$ after Ramadan fasting. Median waist-to-hip circumference ratio of research subjects before Ramadan fasting was $1.03(0.92-1.08)$ and after Ramadan fasting was $0.92(0.80-$ 1.01) $(\mathrm{p}<0.001)$.

\section{Changes in Lipid Profiles and IL-6 Before and After Ramadan Fasting}

Changes in lipid profiles and IL-6 before and after Ramadan fasting can be seen in table 3 .

\section{Table 3. Changes in Lipid Profiles and IL-6 Research Subjects Before and After Ramadan Fasting}

\begin{tabular}{llll}
\hline Characteristics & P1 $(\mathbf{n}=\mathbf{3 0})$ & $\mathbf{P 2}(\mathbf{n}=\mathbf{3 0})$ & $\mathbf{P}$ \\
\hline $\begin{array}{l}\text { Total cholesterol } \\
(\mathrm{mg} / \mathrm{dL})^{\mathrm{a}}\end{array}$ & $199,7 \pm 34,4$ & $185,5 \pm 35,2$ & $0,001^{*}$ \\
$\mathrm{HDL}(\mathrm{mg} / \mathrm{dL})^{\mathrm{a}}$ & $49,4 \pm 8,2$ & $52,5 \pm 8,5$ & $0,049^{*}$ \\
LDL (mg/dL) & $130,1 \pm 28,4$ & $129,0 \pm 32,9$ & 0,729 \\
IL-6 $^{\mathrm{b}}$ & $88 \quad(28,7-$ & $67,75 \quad(23-$ & $<0,001^{* *}$ \\
& $781,6)$ & $596,8)$ & \\
\hline
\end{tabular}

${ }^{a}$ normal distribution, mean $\pm \mathrm{SD}$, paired t test

${ }^{b}$ abnormal data distribution; median (min-max); the Wilcoxon test $* \mathrm{p}<0,05 ; * * \mathrm{p}<0,001$

P1 before the fast of Ramadan

P2 after the fast of Ramadan

There were significant differences in total cholesterol, HDL, and HDL-total cholesterol ratios of research subjects before and after Ramadan fasting ( $<<0.001 ; \mathrm{p}=0.049 ; \mathrm{p}=0.021$ ) (table 4.2). The mean total cholesterol level of the research subjects before Ramadan fasting was $199.7 \pm 34.4 \mathrm{mg} / \mathrm{dL}$ and after Ramadan fasting it was $185.5 \pm 35.2 \mathrm{mg} / \mathrm{dL}$. The mean HDL level of the research subjects before Ramadan fasting was $49.4 \pm 8.2 \mathrm{mg} / \mathrm{dL}$ and after Ramadan fasting it was $52.5 \pm 8.5 \mathrm{mg} / \mathrm{dl}$. The mean HDL-total cholesterol ratio of research subjects before Ramadan fasting was $0.26 \pm 0.07$ and after Ramadan fasting was $0.30 \pm 0.09$. The HOMA-IR value decreased significantly from 2.80 (1.1510.46) before Ramadan fasting to 1.79 (0.07-8.52) after Ramadan fasting.

4. Perbedaan Perubahan Parameter Antropometri dan Laboratorium Sebelum dan Sesudah Puasa Ramadhan Berdasarkan Kategori Tarawih

The differences in changes in anthropometric and laboratory parameters before and after Ramadan fasting based on tarawih categories can be seen in table 4 .

Table 4 Differences in Changes in Clinical and Laboratory Parameters based on Tarawih Categories

\begin{tabular}{|c|c|c|c|c|c|c|c|c|c|c|}
\hline Characteristi & $<15$ days & & & & $>15$ day & & & & & \\
\hline & Before & After & $\Delta$ & $\mathbf{P}$ & Before & After & $\Delta$ & $\mathbf{P}$ & & $\Delta \mathbf{p}$ \\
\hline Weight $(\mathrm{kg})^{\mathrm{a}}$ & $93,4 \pm 20,0$ & $\begin{array}{l}92,4 \pm 2 \\
0,2\end{array}$ & $-(1,03 \pm 1,6)$ & $0,026^{*}$ & $\begin{array}{l}88,2 \pm 1 \\
7,3\end{array}$ & $\begin{array}{l}86,3 \pm 1 \\
6,7\end{array}$ & $-(1$, & $\pm 1,1)$ & $\begin{array}{l}<0,001 \\
* *\end{array}$ & 0,088 \\
\hline
\end{tabular}




\begin{tabular}{|c|c|c|c|c|c|c|c|c|c|}
\hline IMT $\left(\mathrm{kg} / \mathrm{m}^{2}\right)^{\mathrm{a}}$ & $31,6 \pm 5,7$ & $\begin{array}{l}31,3 \pm 5, \\
8\end{array}$ & $\begin{array}{l}- \\
(0,35 \pm 0,57)\end{array}$ & $0,033^{*}$ & $\begin{array}{l}30,4 \pm 4, \\
3\end{array}$ & $\begin{array}{l}29,8 \pm 4, \\
2\end{array}$ & $-(0,68 \pm 0,38)$ & $\begin{array}{l}<0,001 \\
* *\end{array}$ & 0,939 \\
\hline $\begin{array}{l}\text { Waist } \\
\text { circumference } \\
\mathrm{s}(\mathrm{cm})^{\mathrm{a}}\end{array}$ & $102,2 \pm 15,5$ & $\begin{array}{l}100,0 \pm \\
13,9\end{array}$ & $-(2,2 \pm 5,6)$ & 0,147 & $\begin{array}{l}99,6 \pm 1 \\
1,5\end{array}$ & $\begin{array}{l}97,5 \pm 1 \\
0,1\end{array}$ & $-(2,1 \pm 3,5)$ & $0,039 *$ & 0,530 \\
\hline $\begin{array}{l}\text { Hip } \\
\text { circumference } \\
\mathrm{s}(\mathrm{cm})^{\mathrm{a}}\end{array}$ & $110,7 \pm 11,8$ & $\begin{array}{l}108,2 \pm \\
11,2\end{array}$ & $-(2,5 \pm 3,9)$ & $0,028 *$ & $\begin{array}{l}109,9 \pm \\
10,1\end{array}$ & $\begin{array}{l}108,3 \pm \\
9,6\end{array}$ & $-(1,6 \pm 3,5)$ & 0,102 & 0,077 \\
\hline $\begin{array}{l}\text { Total } \\
\text { cholesterol } \\
(\mathrm{mg} / \mathrm{dL})^{\mathrm{a}}\end{array}$ & $200,6 \pm 27,6$ & $\begin{array}{l}190,2 \pm \\
23,7\end{array}$ & $-(10,4 \pm 15,5)$ & $0,021 *$ & $\begin{array}{l}198,9 \pm \\
41,2\end{array}$ & $\begin{array}{l}180,7 \pm \\
44,2\end{array}$ & $-(18,1 \pm 26,5)$ & $0,019 *$ & 0,339 \\
\hline $\mathrm{HDL}(\mathrm{mg} / \mathrm{dL})^{\mathrm{a}}$ & $50,5 \pm 6,5$ & $\begin{array}{l}52,9 \pm 7, \\
5\end{array}$ & $2,3 \pm 4,7$ & 0,075 & $\begin{array}{l}48,3 \pm 9, \\
7\end{array}$ & $\begin{array}{l}52,1 \pm 9, \\
7\end{array}$ & $3,8 \pm 10,8$ & 0,192 & 0,634 \\
\hline $\mathrm{LDL}(\mathrm{mg} / \mathrm{dL})^{\mathrm{a}}$ & $131,9 \pm 22,1$ & $\begin{array}{l}131,0 \pm \\
23,9\end{array}$ & $-(0,9 \pm 12,1)$ & 0,769 & $\begin{array}{l}128,3 \pm \\
34,2\end{array}$ & $\begin{array}{l}127,1 \pm \\
40,8\end{array}$ & $-(1,2 \pm 20,8)$ & 0,826 & 0,917 \\
\hline HOMA-IR ${ }^{b}$ & $\begin{array}{l}3,23 \\
10,46)\end{array}$ & $\begin{array}{l}1,74 \\
(0,87- \\
8,52)\end{array}$ & $\begin{array}{l}-1,14 \quad(-4,27 \\
\text { s/d }-0,44)\end{array}$ & $0,001 *$ & $\begin{array}{l}2,75 \\
(1,15- \\
6,79)\end{array}$ & $\begin{array}{l}1,79 \\
(0,07- \\
4,89)\end{array}$ & $\begin{array}{l}-0,96 \quad(-2,95 \\
\text { s/d } 0,64)\end{array}$ & $0,002^{*}$ & 0,395 \\
\hline
\end{tabular}

${ }^{a}$ normal distribution, mean $\pm \mathrm{SD}$, paired t test

${ }^{\mathrm{b}}$ abnormal data distribution; median (min-max); the Wilcoxon test $* \mathrm{p}<0,05 ; * * \mathrm{p}<0,001$

There were significant differences in body weight before and after Ramadan fasting both in the group with tarawih less than 15 days and in the tarawih group of more than 15 days $(\mathrm{p}=0.026$ vs $p<0.001$ ). We found that weight loss was higher in the group with tarawih more than 15 days than in the group with tarawih less than 15 days ( $1.93 \pm 1.1$ vs $1.03 \pm 1.6)$, but this difference was not statistically significant $(\mathrm{p}=0.088)$.

There were significant differences in body mass index before and after Ramadan fasting both in the group with tarawih less than 15 days and in the tarawih group of more than 15 days ( $p$ $=0.033 \mathrm{vs} p<0.001$ ). The decrease in body mass index was higher in the tarawih group of more than 15 days than the group with tarawih less than 15 days $(0.68 \pm 0.38$ vs $0.35 \pm 0.57)$, but this difference was not statistically significant $(\mathrm{p}=0.939)$.

There were significant differences in waist circumference before and after Ramadan fasting both in the group with tarawih more than 15 days, but there was no significant difference in waist circumference in the tarawih group of fewer than 15 days $(\mathrm{p}=0.039$ $v \mathrm{p}=147$ ). The decrease in waist circumference was higher in the group with tarawih less than 15 days than in the group with tarawih more than 15 days $(2.1 \pm 3.5$ vs $2.5 \pm 3.9)$, but this difference was not statistically significant $(\mathrm{p}=0.530)$.

There were significant differences in total cholesterol before and after Ramadan fasting, both in the tarawih group for less than 15 days and in the tarawih group for more than 15 days $(\mathrm{p}=0.021$ vs $\mathrm{p}=0.019$ ). Total cholesterol reduction was higher in the tarawih group of more than 15 days than the group with tarawih less than 15 days $(18.1 \pm 26.5$ vs $10.4 \pm 15.5)$, but this difference was not statistically significant $(\mathrm{p}=0.339)$.

There were no significant differences in HDL before and after Ramadan fasting, both in the tarawih group of fewer than 15 days and in the tarawih group of more than 15 days ( $\mathrm{p}=0.075 \mathrm{vs} p$ $=0.192$ ). The increase in HDL was higher in the group with tarawih more than 15 days than in the group with tarawih less than
15 days $(3.8 \pm 10.8$ vs $2.3 \pm 4.7)$, but this difference was not statistically significant $(\mathrm{p}=0.634)$.

There were no significant differences in LDL levels before and after Ramadan fasting, both in the tarawih group for less than 15 days and in the tarawih group of more than 15 days $(\mathrm{p}=0.769$ vs $\mathrm{p}=0.826$ ). The reduction in LDL levels was higher in the tarawih group of more than 15 days than the group with tarawih less than 15 days $(1.2 \pm 20.8$ vs $0.9 \pm 12.1)$, but this difference was not statistically significant $(\mathrm{p}=0.917)$.

There were significant differences in the value of HOMAIR before and after Ramadan fasting both in the tarawih group less than 15 days ( $p<0.001)$ and the tarawih group more than 15 days $(\mathrm{p}<0.002)$. The decrease in HOMA-IR values was higher in the group with tarawih of fewer than 15 days than in the group with tarawih of more than 15 days ( $-1.14(-4.27$ to -0.44$)$ vs $-0.96(-2$, 95 to 0.64$)$ ), but this difference was not statistically significant ( $\mathrm{p}$ $=0.395)$.

\section{Correlation of Changes in BMI with Changes in Lipid Profile and HOMA-IR}

There were no changes in BMI with changes in total cholesterol, HDL, LDL, and HOMA-IR (Table 5).

Table 5. Correlation of Changes in BMI with Changes in Total Cholesterol, HDL, LDL, and HOMA-IR

\begin{tabular}{lll}
\hline Variable & $\begin{array}{l}\text { IMT changes } \\
\mathrm{R}\end{array}$ & $\mathrm{P}$ \\
\hline $\begin{array}{l}\text { Total cholesterol } \\
\text { changes }\end{array}$ & $0,178^{*}$ & 0,348 \\
$\begin{array}{l}\text { HDL changes } \\
\text { LDL changes }\end{array}$ & $0,044^{*}$ & 0,819 \\
HOMA-IR changes & $-0,052$ & 0,785 \\
\hline
\end{tabular}

*Spearman Correlation 


\section{Correlation of HOMA-IR Changes with Changes in Total Cholesterol and HDL}

There was no correlation between changes in HOMA-IR with changes in total cholesterol, LDL, and HDL (Table 6).

\section{Table 6. Correlation of HOMA-IR Changes with Changes in} Total Cholesterol and HDL

\begin{tabular}{lll}
\hline $\begin{array}{l}\text { Spearman } \\
\text { Correlation }\end{array}$ & $\begin{array}{l}\text { HOMA-IR } \\
\text { changes }\end{array}$ & \\
& $\mathrm{R}$ & $\mathrm{P}$ \\
\hline $\begin{array}{l}\text { Total cholesterol } \\
\text { changes }\end{array}$ & $-0,020$ & 0,914 \\
$\begin{array}{l}\text { HDL changes } \\
\text { LDL changes }\end{array}$ & $-0,270$ & 0,148 \\
\hline
\end{tabular}

$* \mathrm{p}<0,05$

\section{DISCUSSIONS}

Obesity is a condition that is a risk factor for various diseases (Abdelal et al, 2017). The majority of obese individuals initially lead a lifestyle that is not ideal such as a diet high in calories and fat, consumption of drinks high in simple carbohydrates, lack of physical activity and not exercising regularly. This lifestyle is one of the causes underlying the increase in the prevalence of obesity, which has occurred almost all over the world in the last few decades (Baqai and Wilding, 2015). This lifestyle is common in modern society, especially in urban areas, so that the prevalence of obesity has now increased more than threefold compared to 40 years ago (WHO, 2018). Not only obesity, other diseases associated with obesity such as metabolic syndrome, diabetes mellitus, hypertension, and heart disease, the prevalence tends to increase (Longo et al, 2012; Baqai et al, 2014; Chooi, 2018).

Obesity, which is characterized by an increase in adipose tissue, can be prevented by adopting a healthy lifestyle such as increasing physical activity by exercising regularly and regulating a calorie-balanced diet. Regular exercise of at least 30 minutes per day helps lose weight, reduce body fat levels, increase muscle mass, and not only that, but it also plays an important role in preventing diseases that are at risk of arising in obese individuals. The food diet that is carried out includes adjusting calorie intake with total energy expenditure, a balanced diet, reducing high fat intake, limiting the intake of simple carbohydrates and salt (Gadde and Allison et al, 2009). To limit calorie and fat intake, several studies have revealed the positive impact of limiting food intake for a certain period, this method is better known as intermittent fasting. Adapted from various research sources, intermittent fasting can help reduce inflammation and reduce oxidative stress in the body, reduce systemic insulin levels and fasting blood sugar and increase insulin sensitivity in target tissues. It can also reduce blood pressure, reduce LDL and triglyceride concentrations, which are very beneficial for maintaining a healthy cardiovascular system. Intermittent fasting is also associated with weight loss and can reduce the abdominal fat layer accompanied by significant improvements in metabolic markers (Mazidi et al, 2015; Lushchak et al, 2018). So far, intermittent fasting has been carried out with a variety of very diverse methods and some of them are related to the rituals of worship of a particular religion/belief. In countries where the population is predominantly Muslim, intermittent fasting is routinely carried out for a full month, once a year, so that it can be categorized as prolonged intermittent fasting (Lushchak et al, 2018). This is more popularly known as the fasting of Ramadan.

Ramadan fasting is a mandatory fast for Muslims during the month of Ramadan (one of the months in the Islamic calendar) which has beneficial effects on health. Ramadan fasting is carried out by stopping the total intake of food and drinks from sunrise to sunset. With this, the frequency of large meals is reduced from three times to twice a day and a night, namely before sunrise and after sunset. Apart from that, Muslims are also encouraged to perform "tarawih prayers" either 11 or 23 raka'at with a duration of 1-2 hours continuously which is considered to equal moderate physical activity. During the fasting month of Ramadan, it is recommended to control emotions and lust. The existence of a smoking ban during the day has an impact on reducing the frequency of smoking for a smoker in the month of Ramadan. Some changes in the lifestyle during a month are thought to affect a person's health status (Shehab et al, 2012; Lushchak et al, 2018; Mirmiran et al, 2019).

We have encountered several positive effects of Ramadan fasting in this study, including weight loss and BMI in obese individuals undergoing Ramadan fasting. The mean body weight decreased significantly from $90.8 \pm 18.6 \mathrm{~kg}$ to $89.4 \pm 18.5 \mathrm{~kg}$ after Ramadan fasting ( $\mathrm{p}<0.001)$. The median BMI decreased significantly from $29.2 \mathrm{~kg} / \mathrm{m} 2$ to $28.8 \mathrm{~kg} / \mathrm{m} 2$ ( $\mathrm{p}<0.05$ ). Likewise with other anthropometric parameters such as waist circumference with a significant decrease in the mean of $2.2 \mathrm{~cm}(\mathrm{p}=0.016)$, a significant decrease in the mean hip circumference of $2 \mathrm{~cm}(\mathrm{p}=$ 0.005 ) and a significant decrease in the mean waist/hip ratio from $100.9 \pm 13$. , $5 \mathrm{~cm}$ becomes $98.7 \pm 12.0 \mathrm{~cm}(\mathrm{p}=0.016)$. Weight loss is thought to be due to a decrease in calorie intake during the fasting month of Ramadan. This was found in the study of Shariatpanahi et al, where a decrease in mean body weight of 1.96 $\pm 1.35 \mathrm{~kg}$ was accompanied by a decrease in calorie intake of $234.6 \pm 88.2 \mathrm{~kJ}$ per day (Shariatpanahi et al, 2008). The majority of other studies have found similar results. Mazidi et al in a systematic review of the effects of Ramadan fasting on cardiometabolic and anthropometric parameters reported that of 16 studies on Ramadan fasting from 1982 to 2012, 10 of them found weight loss after Ramadan fasting, while a decrease in BMI was found in 6 studies (Mazidi et al, 2015). Some of these studies, namely by Shehab et al., Found a decrease in mean body weight of $1.1 \mathrm{~kg}(\mathrm{p}=0.003)$ and a decrease in mean BMI from $28.1 \pm 4.4$ $\mathrm{kg} / \mathrm{m} 2$ to $27.8 \pm 4.4 \mathrm{~kg} / \mathrm{m} 2 .(\mathrm{p}=0.003)$ (Shehab et al, 2012). Sadiya et al also found a decrease in mean body weight from 103.9 $\pm 29.8 \mathrm{~kg}$ in one week before Ramadan fasting to $102.1 \pm 29.0 \mathrm{~kg}$ ( $\mathrm{p}<0.01)$ in the fourth week after Ramadan fasting. Besides, there was also a decrease in BMI from $40.2 \pm 10.2 \mathrm{~kg} / \mathrm{m} 2$ to $40.0 \pm$ $10.5 \mathrm{~kg} / \mathrm{m} 2(\mathrm{p}<0.05)$, and a decrease in the mean waist circumference from $123 \pm 14.0 \mathrm{~cm}$ to $119 . \pm 17.0 \mathrm{~cm}(\mathrm{p}<0.05)$. In that study, all of the study samples were women, with a median number of fasting days of 26.2 days and an average fasting duration of 14 hours $20 \pm 10$ minutes per day (Sadiya et al, 2011). A decrease in the mean waist/hip ratio was also obtained by Nematy et al with a mean decrease of $1.6 \pm 9 \mathrm{~cm}(\mathrm{p}<0.001)$ (Nematy et al, 2012). The weight loss found in the above study 
may be due to reduced frequency of eating, which reduces the calorie intake and increases in physical activity. Besides, during fasting, there is also a change in sleep patterns. This change in sleep patterns causes changes in levels of leptin, neuropeptide-Y, and insulin which play an important role in the regulation of appetite in the long term (Shariatpanahi, 2008).

This study also found a positive effect of Ramadan fasting on the lipid profile between a significant reduction in total cholesterol levels $(p<0.001)$ and a significant increase in HDL levels ( $p=0.049$ ) of research subjects after Ramadan fasting. LDL levels did not change significantly. In line with these findings, a meta-analysis by Mirmiran et al who performed an analysis of 33 studies from the Pubmed, Scopus, and Embase databases on the effects of Ramadan fasting on lipid profile parameters, found that Ramadan fasting had a positive effect on serum HDL-Good. in healthy individuals, pregnant women and athletes. We found a significant increase in HDL in men than in women $(2.18 \mathrm{mg} / \mathrm{dl} \mathrm{vs}$ $0.23 \mathrm{mg} / \mathrm{dl})$. Individuals with a high baseline triglyceride value had a greater decrease in triglycerides. From this study, we also knew that the decrease in LDL-C and triglycerides obtained by age and weight loss (Mirmiran et al, 2019). Research by Shehab et al. Concluded that Ramadan fasting or a similar diet pattern has a positive effect on the improvement of lipid profiles which increases HDL levels and decreases LDL levels. Participants comprised 60 adults (42 males and 18 females), measurements were taken on the first day of fasting (pre-Ramadan), the last day of fasting (Ramadan), and 4 weeks after the end of the fasting month of Ramadan (post-Ramadan). The results showed that the mean increase in HDL-C increased significantly, followed by a decrease in LDL-C in both men and women $(\mathrm{P}=0.001)$. However, the improvements in HDL-C and LDL-C were not accompanied by good changes in total cholesterol and triglycerides. This is thought to be due to the consumption of foods with high saturated fatty acid content during Ramadan, however, data on calorie intake and types of food during Ramadan cannot be collected so this assumption cannot be confirmed (Shehab et al, 2012). Shariatpanahi et al. reported a significant increase in mean HDL$\mathrm{C}$ (from $41.55 \pm 5.45 \mathrm{mg} / \mathrm{dl}$ to $46.66 \pm 5.50 \mathrm{mg} / \mathrm{dl}, \mathrm{p}=0.02$ ) in individuals with metabolic syndrome who underwent full Ramadan fasting. In this study, calorie intake data before and during fasting were calculated and found a decrease in fat intake during fasting (Shariatpanahi Z. et al, 2012). This study is in line with Akaberi et al. who found an increase in HDL-C after Ramadan fasting from $33.10 \pm 6.53$ before fasting to $42.49 \pm 8.44$ with $\mathrm{p}<0.001$. LDL-C increased from $93.21 \pm 24.55$ to $98.36 \pm$ 21094 with $\mathrm{p}=0.003$. An increase in total cholesterol but no change in triglyceride levels. Nematy et al found that a decrease in total cholesterol (from $193.4 \pm 51$ to $184.3 \pm 42$ ), a decrease in LDL-C (from $109.96 \pm 46$ to $96.83 \pm 35$ ), a decrease in the cholesterol / HDL ratio (from $4.5 \pm 1$ to $3.9 \pm 1$ ), the LDL / HDL ratio (from $2.5 \pm 0.8$ to $2.0 \pm 0.6$ ) and the increase in HDL-C (from $43.0 \pm 9$ to $47.9 \pm 8$ ) were significant ( $p=0.02$; HDL-C $p<0.001$ ). The differences in the above results may be due to the diversity of types of food, socio-economic status, race, lifestyle in the different countries where the study was conducted, the health status, and the medical history of the study subjects. But in total, there were improvements in lipid profiles after Ramadan fasting (Nematy et al, 2012).
The results of this study indicate that Ramadan fasting has a beneficial effect on increasing insulin sensitivity in obese individuals. We can see this from the significant decrease in the value of HOMA-IR before and after fasting. HOMA-IR is an accurate method for determining insulin resistance in both epidemiological and clinical studies. In nondiabetic individuals, the HOMA-IR value is above 1.85 in men and above 2.07 in women who are said to be individuals who have insulin resistance and have an increased risk of developing cardiometabolic disease (Gayoso-Diz et al, 2013). Various studies have concluded that there is a strong relationship between obesity and insulin resistance (Richelsen B and Pedersen SB. 1995; Shariatpanahi et al., 2008). Researchers realized that the increase in insulin sensitivity found in the study subjects was closely related to the reduction in body weight and body mass index after undergoing Ramadan fasting. Weight loss and other anthropometric parameters are most likely because of changes in diet, from 3 times a day to 2 times a day, and the prohibition of eating and drinking for about 13-14 hours. Daily activities that have increased, namely the presence of religious activities at night, also affect this result. This weight loss and anthropometric index reflect a decrease in energy intake and an increase in energy expenditure during the fasting month of Ramadan. Changes in the frequency and hours of eating, activity, and sleep patterns changes in leptin, neuropeptide, and insulin levels which are known to be important in regulating energy intake and energy expenditure (Kassab et al, 2004). It has been previously known that visceral fat in obese individuals produces various inflammatory mediators that interfere with insulin signaling pathways and cause insulin resistance $(\mathrm{Wu}$ and Ballantyne, 2020). We can presume the improvement in insulin sensitivity in this study due to the decrease in visceral fat volume, which directly / indirectly reduces the pro-inflammatory state during Ramadan fasting. Unfortunately, this study did not measure the various inflammatory mediators that influence insulin signaling pathways. In the future, we need bigger research with more complete variables to ensure this.

In line with the results, Shariatpanahi et al. also restoration of insulin sensitivity in individuals with metabolic syndrome undergoing Ramadan fasting. In this study, the parameters used were QUICKI (quantitative insulin sensitivity examination index), HOMA-IR, and reverse HOMA-IR. The QUICKI and reverse HOMA-IR values increased significantly while the HOMA-IR values decreased, but not significantly. This study also found a decrease in body weight of $1.96( \pm 1.35) \mathrm{kg}$ and a decrease in calorie intake of $234.6( \pm 88.2) \mathrm{kJ} /$ day during Ramadan fasting (Shariatpanahi et al, 2008). Ünalacak et al who studied the effects of Ramadan fasting on biochemical and hematological parameters and cytokines in healthy and obese individuals found a significant reduction in the value of HOMA-IR in obese patients after Ramadan fasting. However, in healthy individuals, a significant increase in HOMA-IR was found. Researchers attributed this to the increase in insulin levels found in healthy individuals, although the increase was not significant. In that study, researchers also found a significant reduction in inflammatory mediators such as IL-2, IL-8 and TNF- $\alpha$ compared to basal values in healthy and obese individuals. Researchers estimate that a state of prolonged fasting such as Ramadan fasting can improve the inflammatory status of the body regardless of obesity or non-obese status (Ünalacak et al, 2011). Prasetya and Supwarobol in their research 
found that insulin and HOMA-IR levels decreased significantly by $10 \%$ from the baseline value and that the QUICKI value increased significantly by $5 \%$ from the baseline value after Ramadan fasting. Researchers argue that the reduction in body weight, fat mass, and waist circumference found in research subjects are factors that affect the increase in insulin sensitivity (Prasetya and Sapwarobol, 2018).

From this study, there were no significant changes in body weight, anthropometric index, laboratory parameters, and insulin resistance index between the group that prayed tarawih less than 15 days and the group that prayed tarawih for more than 15 days. Mokhtar and Ibrahim's research found changes in body composition after 20 days of fasting and tarawih prayers routinely measured by bioelectrical impedance analysis (BIA). In this study, we found an increase in basal metabolic rate and lean body mass and a significant decrease in fat mass and blood glucose levels ( $\mathrm{p}$ $<0.05$ ) (Mokhtar and Ibrahim, 2008). The differences found with the results of this study are thought to be due to bias in terms of the number of raka'ats for tarawih prayers and the duration of tarawih prayers. On the other hand, researchers also take that regular messages are still needed to maximize the positive effects of the Ramadan fast.

Although there have been many studies that concluded that insulin sensitivity can be improved by reducing body weight, fat mass, and waist circumference, such as Shariatpanahi et al who found that increasing linear insulin sensitivity with a decrease in waist circumference, in this study, researchers did not find a significant correlation. between changes in BMI with changes in HOMA-IR (Shariatpanahi et al, 2008). In future studies, researchers recommend using other parameters such as QUICKI and reverse HOMA-IR or other insulin resistance measurement methods to be correlated with more accurate anthropometric parameters of results. In several studies, changes in lipid profiles correlated with weight loss, but in this study, there was no correlation between changes in lipid profiles with changes in BMI. This study is one of the few studies that assessed changes in lipid profiles and insulin resistance in obese individuals observing the Ramadan fast. However, this study also has limitations, including the absence of a control group (the group that is not fasting on Ramadan) as a comparison. The value obtained is a comparison of the basic values with the values found after the fasting of Ramadan. Also, there were no measurements of daily calorie intake, recording of dietary habits, types of food eaten, degree of daily activity, and sleep patterns which may be correlated with research results or may cause bias.

\section{CONCLUSION}

This study found a decrease in body weight, BMI, waist circumference, hip circumference, and waist/hip ratio, a decrease in total cholesterol levels, an increase in HDL levels, a statistically significant decrease in HOMA-IR in obese individuals undergoing Ramadan fasting, whereas LDL levels also decreased but not statistically significant. Researchers did not find any correlation between changes in BMI with changes in total cholesterol, HDL, LDL, and HOMA-IR.

\section{REFERENCES}

[1] Abdelaal, M., Ie-Roux, C.W., dan Docherty, N.G. 2017. Morbidity and Mortality Associated with Obesity. Ann Transl med, 5(7):161-74.

[2] Akaberi, A., Golshan, A., Moojdekanloo, M., Hashemian, M. 2014. Does Fasting in Ramadan Ameliorate Lipid Profile? A Prospective Observational Study. Pak J Med Sci, 30(4):708-11.

[3] Aksungar, F. B., Topkaya, A. E., dan Akyildiz, M. 2007. Interleukin-6, CReactive Protein and Biochemical Parameters during Prolonged Intermittent Fasting. Ann Nutr Metab, 51:88-95.

[4] Arora M., Koley, S., Gupta, S., Sandhu, J.S. 2016. A Study on Lipid Profile And Body Fat in Patients with Diabetes Mellitus. Anthropologist, 9(4):295258 .

[5] Baqai, N. and Wilding, J.P.H. 2015. Pathophysiology and Aetiology of Obesity. Medicine, 43(2):73-6.

[6] Baqai, N. dan Wilding, J.P.H. 2015. Pathophysiology and Aetiology of Obesity. Medicine, 43(2):73-6.

[7] Bays, H.E., Toth, P.P., Kris-Etherton, P.M., Abate, N., Aronne, L.J., Brown, W.V., et al. 2013. Obesity, Adiposity, and Dyslipidemia: A Consensus Statement from the National Lipid Association. J Clin Lipidol, 7(4):304-83.

[8] Chen J., Wildman, RP. Hamm, LL. Muntner, P. Reynolds, K. Whelton, PK He, J. 2004. Association Between Inflammation and Insulin Resistance in U.S. Nondiabetic Adults: Results from the Third National Health and Nutrition Examination Survey. Diabetes Care, 27(12): 2960-65.

[9] Chooi, Y.C., Ding, C., dan Magkos, F. 2018. The Epidemiology of Obesity. Metabolism, 92:6-10.

[10] Ellulu, M.S. Patimah, I., Khaza'ah, H., Rahmat, A. Abed, Y. 2017. Obesity and Inflammation: The Linking Mechanism and the Complications. Archives of medical science AMS, 13(4):851-63.

[11] Faris, M.A.E., Kacimi, S., Al-Kurd, R.A., Fararjeh, M.A., Bustanji, Y.K. Mohammad, M.K et al. 2012. Intermittent Fasting During Ramadan Attenuates Proinflammatory Cytokines and Immune Cells in Healthy Subjects. Nutrition Research Elsevier, 32:947-55

[12] Fontana, L., Eagon, J.C., Trujillo, M.E., Scherer, P.E., Klein, S. Visceral Fat Adipokine Secretion is Associated with Systemic Inflammation in Obese Humans. Diabetes, 56:1010-3.

[13] Gadde KM, Allison DB. 2009. Combination therapy for obesity and metabolic disease. Curr Opin Endocrinol Diabetes Obes 2009;16:353-8.

[14] Gayoso-Diz P, Otero-González A, Rodriguez-Alvarez MX, Gude F, García F, De Francisco A, Quintela AG. 2013. Insulin resistance (HOMA-IR) cutoff values and the metabolic syndrome in a general adult population: effect of gender and age: EPIRCE cross-sectional study. BMC Endocr Disord, $16 ; 13: 47$.

[15] Kassab S, Abdul-Ghaffar T, Nagalla DS, Sachdeva U \& Nayar U. 2004 Interactions between leptin, neuropeptide-Y, and insulin with chronic diurnal fasting during Ramadan. Ann Saudi Med, 24:345-49.

[16] Longo, D. 2012. Harrisons Manual of Medicine, 18th Edition. US: McGrawHill Professional.

[17] Lumeng CN, Saltiel AR. 2011. Inflammatory links between obesity and metabolic disease. J Clin Invest, 121:2111-7.

[18] Lushchak, O., Strilbyska, O., Piskovatska, V., Koliada, A., Storey, K.B. 2018. Intermittent Fasting. Elsevier: 1-10.

[19] Mattsona, M.P., Longo, V.D., Harvie, M. 2016. Impact of Intermittent Fasting on Health and Disease Processes. Ageing Research Reviews, 39:4658.

[20] Mazidi, M., Rezaie, P., Chaudhri, O., Karimi, E., Nematy, M. 2015. The Effect of Ramadan Fasting on Cardiometabolic Risk Factors and Anthropometrics Parameters: A Systematic Review. Pak J Med Sci, 31(5): 1250-55.

[21] Mirmiran, P., Zahra, B., Gaeini, Z., Moslehi, N., Azizi, F. 2019. Effects of Ramadan Intermittent Fasting on Lipid and Lipoprotein Parameters: An Updated Meta-Analysis. Nutrition, Metabolism \& Cardiovascular Diseases. 29(9):906-15.

[22] Mohammadzade, F., Vakili, M.A., Seyediniaki, A., Amirkhanloo, S., Farajolahi, M. Akbari, H., et al. 2017. Effect of Prolonged Intermittent Fasting in Ramadan on Biochemical and Inflammatory Parameters of Healthy Men. Journal of Clinical and Basic Research (JCBR), 1(1):38-46.

[23] Mokhtar, M.S. dan Ibrahim, F. 2008. Assessment of Salat Taraweeh and Fasting Effect on Body Composition. In: 4th Kuala Lumpur International Conference on Biomedical Engineering 2008, Biomed 2008, Kuala Lumpur.

This publication is licensed under Creative Commons Attribution CC BY. 
[24] Nematy M, Alinezhad-Namaghi M, Rashed MM, Mozhdehifard M, Sajjadi SS, Akhlaghi S, Sabery M, Mohajeri SA, Shalaey N, Moohebati M, Norouzy A.2012. Effects of Ramadan fasting on cardiovascular risk factors: a prospective observational study. Nutr J. 2012 Sep 10;11:69. doi: 10.1186/1475-2891-11-69. PMID: 22963582; PMCID: PMC3487759.

[25] Ongsara S, Boonpol S, Prompalad N, Jeenduang N. 2017. The Effect of Ramadan Fasting on Biochemical Parameters in Healthy Thai Subjects. J Clin Diagn Res 2017; 11:Bc14-bc18.

[26] Patterson R.E. Laughlin, G.A., LaCroix A.Z., Hartman, S.J., Natajaran, L. Senger, C.M., et al. 2015. Intermittent Fasting and Human Metabolic Health. J Acad Nutr Diet,115(8):1203-12.

[27] Prasetya, G. and Sapwarobol, S. 2018. Intermittent Fasting During Ramadan Improves Insulin Sensitivity and Anthropometric Parameters in Healthy Young Muslim Men. American Journal of Lifestyle Medicine. DOI: $10.1177 / 1559827618815430$.

[28] Richelsen B dan Pedersen SB. 1995. Associations between different anthropometric measurements of fatness and metabolic risk parameters in non-obese, healthy, middle-aged men. Int J Obes Relat Metab Disord, 19:169-74

[29] Sadiya, A., Ahmed, S., Siddieg, H. H., Babas, I. J., \& Carlsson, M. (2011). Effect of Ramadan fasting on metabolic markers, body composition, and dietary intake in Emiratis of Ajman (UAE) with metabolic syndrome. Diabetes, metabolic syndrome, and obesity: targets and therapy, 4, 409-416. https://doi.org/10.2147/DMSO.S24221.

[30] Shariatpanahi MV, Shariatpanahi ZV, Shahbazi S, Moshtaqi M. Effect of fasting with two meals on BMI and inflammatory markers of metabolic syndrome. Pak J Biol Sci. 2012 Mar 1;15(5):255-8. doi: 10.3923/pjbs.2012.255.258. PMID: 24199461.

[31] Shariatpanahi, Z.V., Shariatpanahi, M.V., Shahbazi, S., Hossaini, A., Abadi, A. 2008. Effect of Ramadan Fasting on Some Indices of Insulin Resistance and Components of the Metabolic Syndrome in Healthy Male Adults. British Journal of Nutrition, 100(1):147-51
[32] Shehab, A., Abdulle, A., El-Issa, A., Al-Suwaidi, J., Nagelkerke. 2012. Favorable Changes in Lipid Profile: the Effect of Fasting after Ramadhan. Plos One, 7(10):e47615.

[33] Unalacak, M., Kara, I.H., Baltaci, D., Erdem, O., Bucaktepe, PG. 2011. Effects of Ramadan Fasting on Biochemical and Hematological Parameters and Cytokines in Healthy and Obese Individuals. Metab Syndr Relat Disord, 9(2):157-61.

[34] World Health Organization. Obesity and Overweight. 2018 (https://www.who.int/news-room/fact-sheet/detail/obesity-and-overweight accessed date August 9th, 2019).

[35] Wu, H. dan Ballantyne, C.M. 2020. Metabolic Inflammation and Insulin Resistance in Obesity. Circulation Research, 126:1549-64.

[36] Ye, J. 2013. Mechanisms of insulin resistance in obesity. Front Med, 7(1): $14-24$.

\section{AUTHORS}

First Author - Frihastina Lubis, Division of Endocrinology and Metabolic Diseases, Department of Internal Medicine, Faculty of Medicine Universitas Sumatera Utara

Second Author - Santi Syafril, Division of Endocrinology and Metabolic Diseases, Department of Internal Medicine, Faculty of Medicine Universitas Sumatera Utara

Third Author - Dharma Lindarto, Division of Endocrinology and Metabolic Diseases, Department of Internal Medicine, Faculty of Medicine Universitas Sumatera Utara 